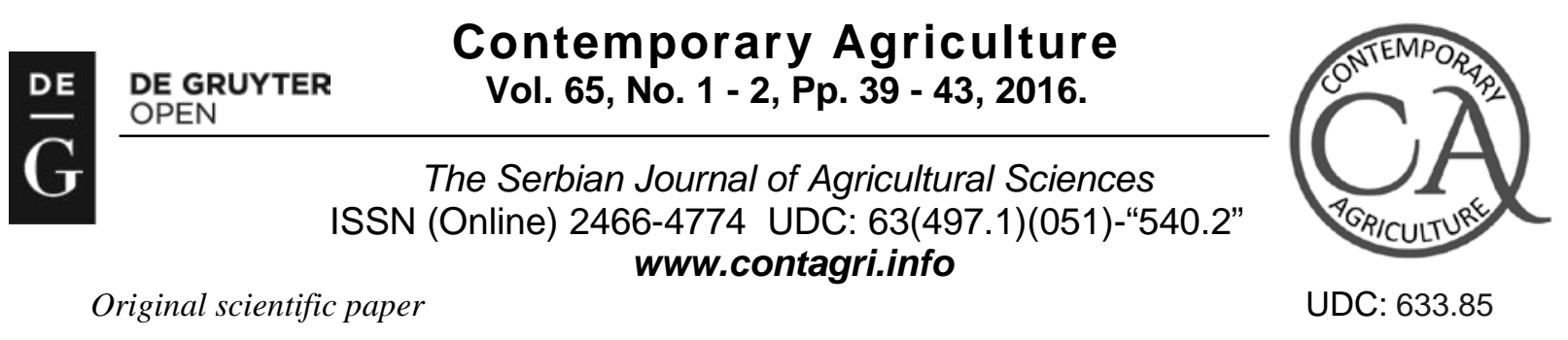

DOI: 10.1515/contagri-2016-0007

\title{
EVALUATION OF SUNFLOWER GENOTYPES FOR ORNAMENTAL USE
}

\author{
Emina MLADENOVIĆ ${ }^{1}$, Sandra CVEJIĆ ${ }^{2}$, Jelena ČUKANOVIĆ ${ }^{1}$, Gordana ŽERAVICA ${ }^{1}$, \\ Siniša JOCIĆ ${ }^{2}$
}

\begin{abstract}
Summary: Sunflower (Helianthus annuus L.) is a species with interspecies variability, especially in qualitative traits. From horticultural point of view it is important to choose genotypes with desired characteristics. Knowing of genotypes characteristics is essential to choose the correct genotypes that can be used in gardens and like cut flowers. Present research was carried out at Institute of Field and Crops at Rimski Šančevi in Novi Sad, Serbia. Experiment included four genotypes of ornamental sunflower. Significant variation for morphological traits were observed. Qualitative characteristics such as flower color, also showed great variability. Base on the results all genotypes can be recommended as garden plants and cut flowers.
\end{abstract}

Key words: ornamental sunflower, variability, morphological traits, flower color

\section{INTRODUCTION}

Sunflower have been one of most important source of oil and antioxidants (Dragičević et al., 2010) and represent one of major field crops in Serbia (Bošnjak et al., 2013; Kaya et al., 2012). The development of horticulture and floriculture has led to the use of sunflower as an ornamental plant, in gardens, in pots or like cut flower. For ornamental sunflowers main aims are desirable plant architecture, color of ray and disc flowers and flowering period (Miklić et al. 2008). Success in breeding work may only be achieved with a large variability in the population (Cvejić et al. 2011).

For lovers and growers of flowers, sunflowers have effective and decorative features and a number of good qualities. It is easy to be grown in almost all locations that are not picky by type of land and it does not require much effort. They are used for interior decorating, gardens and variety of public green spaces. Their height is particularly interesting for the isolation and camouflage unsightly fences and houses but also like hedges. In the flower shops sunflowers are successfully sold as a cut flower. Flower producers are particularly interested in the variation in flower color, structure of the ray flower and length flower handle (Šećerov-Fišer 1985). Cut flower should be characterized by a lot of straight and a long stem, with less branching, while garden flower is with less and more branched stem. Single-stem plants need to have large flowers, while one that is characterized by a branch of a small central flower with several side, even smaller, flowers (Cvejić et al. 2010). Ornamental sunflower is the species that includes many genotypes with different color of ray and disc flowers, branching type and height. Number of ray flowers is a very important characteristic for ornamental sunflower (Šećerov-Fišer et al. 1995). The flowers of sunflower are collected in inflorescence-head, where the quantities in ornamental sunflowers varied widely. The blossoms are composed of disc and ray flowers. Disc flowers are fertile and are located throughout the interior surface of the head. Ray flowers are located around the circumference of the head and sterile. According Cvejić et al. (2010) because of extending the life of flowers sunflower it is necessary that the disc flower is sterile flowers i.e. that do not produce pollen. According to Miklič et al. (2008) in order to avoid pollen allergy should be used genotypes with sterile flowers. The aim of this study is to analyze characteristics of four sunflower genotypes with potential ornamental use.

\footnotetext{
${ }^{1}$ Emina Mladenović PhD, associate professor, Jelena Čukanović, PhD, associate professor, Gordana Žeravica, student University of Novi Sad, Faculty of Agriculture, Trg Dositeja Obradovića 8, Serbia;

${ }^{2}$ Sandra Cvejić, PhD, research scientists, Siniša Jocić, PhD, Principal Research Fellow, Institute of Field and Vegetable Crops, Maksima Gorkog 30, Novi Sad, Serbia;

*Corresponding author: Emina Mladenović, e-mail: eminam@polj.uns.ac.rs; phone: +381 214853269
} 


\section{MATERIAL AND METHODS}

The field trial was conducted at Rimski Šančevi experimental field of the Institute of Field and Crops in Novi Sad, Serbia in season 2015. There were four genotypes of ornamental sunflower. The experimental plot was organized in a randomized complete block design with three replications. Each plot consisted of four rows, with row-to-row spacing $0.70 \mathrm{~m}$ and plant-to-plant spacing $0.3 \mathrm{~m}$ (4.5 m long rows). All necessary agricultural practices typical for sunflower production were performed. Measurements were performed on 30 plants in the middle rows (10 plants per replication) during flowering. Investigated genotypes were Heliopa, Talia, Iskra and Neoplanta. In the paper we used abbreviation for the genotypes, and this in the following way: GZ13 for Heliopa, GZ16 for Talia, GZ21 for Iskra and GZ37 for Neoplanta.

Both quantitative and qualitative features were followed. Features include: number of days from germination till flowering of central head (NDFCH), number of days from germination till flowering of first lateral head (NDFLH), number of days from germination till end of lateral heads flowering (NDELH), number of ray flowers (NRF), plant height $(\mathrm{PH})$, the diameter of the central head $(\mathrm{DCH})$, length of ray flowers in central head (LCH), the number of branches (NB), length of lateral branches (LLB), the diameter of the lateral disk flowers (DF), length of ray flowers in lateral head (LR), number of ray flowers in lateral heads (NR), stem diameter (DS) and stem diameter of lateral branches (DLS). Analyzed qualitative traits were color of ray and disc flowers.

The collected data was processed using STATISTICA 13 SOFTWARE application (StatSoft, Inc., Tulsa, OK, USA), using Principal Component Analysis (PCA).

\section{RESULTS}

The results of morphological analysis of four ornamental sunflower genotypes indicate that number of days from germination till flowering of central head ranged from 48.76 days (GZ16) to 65.43 days (GZ21), and moderate variability (CV=13.59\%) (Table 1). Moreover, very high variability is observed in the number of ray flowers in lateral heads $(\mathrm{CV}=26.67 \%)$. This indicates that the feature that carries a lot of decoration is very variable in these genotypes, and the combination can achieve unusual and harmonious landscape selection. Second feature that is also very variable was the number of branches ( $\mathrm{CV}=22.14 \%)$. Number of branches is a feature that has a significant impact on the shape of the plant habit. Genotypes with a large number of lateral branches are recommended as garden plants. At the same time a large number of medium size flowers may be used for making arrangements and bouquets.

Table 1. Means and variances of ornamental sunflower (Helianthus annuus L.) genotypes

\begin{tabular}{|c|c|c|c|c|c|c|c|c|c|c|c|c|c|c|c|}
\hline No & Genotype & $\mathrm{NDFCH}$ & NDFLH & NDELH & NRF & $\mathrm{PH}$ & DCH & LCH & NB & LLB & $\mathrm{DF}$ & LR & NR & DS & DLS \\
\hline 1 & GZ13 & 56,03 & 64,8 & 81,33 & 33,46 & 121,16 & 7,08 & 3,38 & 18,53 & 30,28 & 5,98 & 3,1 & 24,33 & 5,46 & 0,82 \\
\hline 2 & GZ16 & 48,76 & 57,76 & 82,1 & 28,93 & 138,83 & 8,28 & 4,63 & 15,66 & 38,29 & 6,66 & 3,81 & 22,23 & 5,8 & 0,66 \\
\hline 3 & GZ21 & 65,43 & 71,23 & 85 & 39,56 & 187,33 & 8,05 & 3,95 & 17,46 & 41,11 & 6,40 & 3,07 & 38,5 & 5,86 & 0,73 \\
\hline 4 & GZ37 & 50,50 & 61,83 & 74,96 & 44,46 & 147,5 & 8,06 & 4,12 & 10,73 & 39,64 & 6,53 & 3,16 & 35,36 & 5,43 & 0,74 \\
\hline \multicolumn{2}{|c|}{ Mean } & 55,18 & 63,90 & 80,85 & 36,60 & 148,70 & 7,87 & 4,02 & 15,59 & 37,33 & 6,39 & 3,28 & 30,10 & 5,64 & 0,74 \\
\hline \multicolumn{2}{|c|}{ Minimum } & 48,76 & 57,76 & 74,96 & 28,93 & 121,16 & 7,08 & 3,38 & 10,73 & 30,28 & 5,98 & 3,07 & 22,23 & 5,43 & 0,66 \\
\hline \multicolumn{2}{|c|}{ Maximum } & 65,43 & 71,23 & 85 & 44,46 & 187,33 & 8,28 & 4,63 & 18,53 & 41,11 & 6,66 & 3,81 & 38,50 & 5,86 & 0,82 \\
\hline \multicolumn{2}{|l|}{ SD } & 7,50 & 5,67 & 4,23 & 6,81 & 27,98 & 0,53 & 0,51 & 3,45 & 4,84 & 0,29 & 0,35 & 8,03 & 0,22 & 0,06 \\
\hline \multicolumn{2}{|c|}{ CV (\%) } & 13,59 & 8,88 & 5,23 & 18,61 & 18,82 & 6,81 & 12,82 & 22,14 & 12,96 & 4,61 & 10,71 & 26,67 & 3,97 & 8,88 \\
\hline \multicolumn{2}{|c|}{ LSD 0.01} & 24,61 & 18,81 & 15,03 & 32,95 & 91,06 & 2,54 & 1,98 & 11,74 & 19,77 & 1,26 & 1,25 & 26,67 & 0,88 & 0,43 \\
\hline \multicolumn{2}{|c|}{ LSD 0.05} & 17,13 & 13,09 & 10,46 & 22,93 & 63,38 & 1,77 & 1,37 & 8,17 & 13,76 & 0,88 & 0,87 & 18,57 & 0,62 & 0,30 \\
\hline
\end{tabular}

According to the multivariate principal component analysis, the most variable among examined parameters were number of days from germination till flowering of central head, number of days from germination till flowering of first lateral head, plant height and number of ray flowers in lateral heads. These parameters loaded on the PC1 with total variation by $45.64 \%$. The PC2 axis accounted for further $32.26 \%$ of the total variance and was defined by the diameter 
of the central head, length of ray flowers in central head, the number of branches, length of lateral branches and the diameter of the lateral disk flowers (Table 1 and Table 2). Number of days from germination till end of lateral heads flowering, the number of branches and stem diameter were most variable according to PC3, and contributed to the total variation by $22.09 \%$. Scatter plot showed separation of genotypes GZ16 and GZ37 (Graph. 1). These two genotypes were singled out on the basis of similar traits measured.

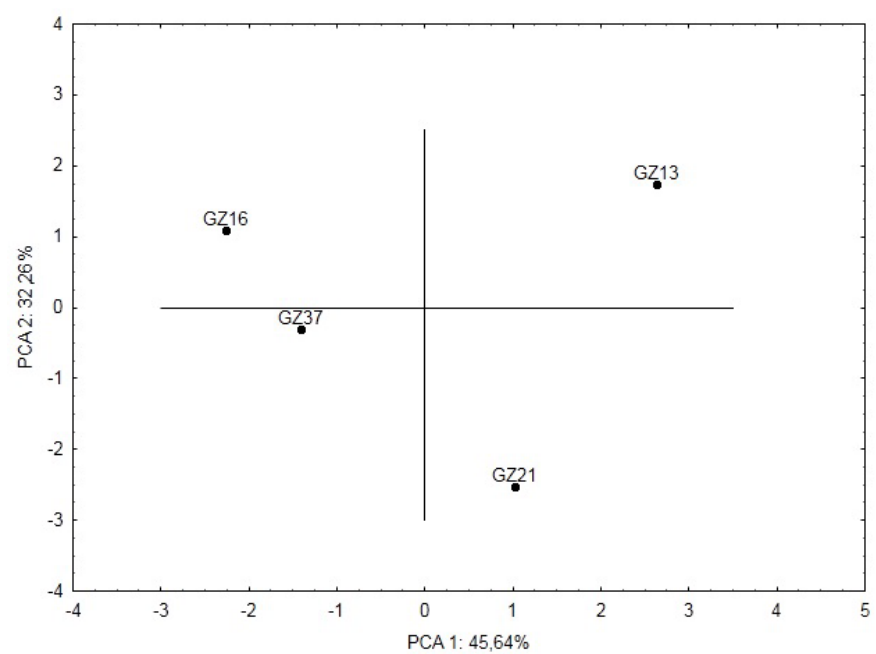

Graph. 1. Multivariate principal component analysis scatterplot based on morphological parameters of ornamental sunflower

Table 2. Principal Component Analysis of different traits

\begin{tabular}{|c|c|c|c|}
\hline Principal component & Eigenvalue & $\begin{array}{c}\text { Proportion of variation } \\
(\%)\end{array}$ & Cumulative \\
\hline 1 & 5.02 & 45.64 & 45.64 \\
\hline 2 & 3.55 & 32.26 & 77.91 \\
\hline 3 & 2.43 & 22.09 & 100.00 \\
\hline
\end{tabular}

Table 3. Principal components of various traits

\begin{tabular}{|l|c|c|c|}
\hline Characters & Principal & components & PC3 \\
\hline & PC1 & 0,21 & 0,14 \\
\hline NDFCH & $\mathbf{0 , 9 2}$ & 0,14 & 0,01 \\
\hline NDFLH & $\mathbf{0 , 9 5}$ & 0,33 & $\mathbf{0 , 8 1}$ \\
\hline NDELH & 0,38 & 0,13 & $-0,69$ \\
\hline NRF & 0,25 & 0,69 & $-0,11$ \\
\hline PH & $\mathbf{0 , 6 4}$ & $\mathbf{0 , 8 0}$ & $-0,15$ \\
\hline DCH & $-0,28$ & $\mathbf{0 , 6 8}$ & 0,51 \\
\hline LCH & $-0,42$ & $-0,13$ & $\mathbf{0 , 7 9}$ \\
\hline NB & 0,39 & $\mathbf{0 , 8 3}$ & $-0,30$ \\
\hline LLB & 0,03 & $\mathbf{0 , 6 7}$ & $-0,26$ \\
\hline DF & $-0,44$ & 0,46 & 0,29 \\
\hline LR & $-0,77$ & 0,37 & $-0,56$ \\
\hline NR & $\mathbf{0 , 6 8}$ & 0,46 & $\mathbf{0 , 5 9}$ \\
\hline DS & 0,21 & $-0,34$ & 0,12 \\
\hline DLS & 0,29 & & \\
\hline
\end{tabular}


All investigated ornamental sunflower genotypes show great importance in horticulture (Picture 1 a-d), due to their decorativeness.

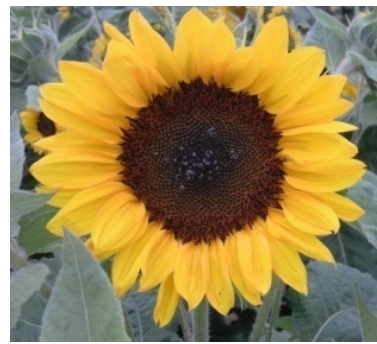

a) GZ13

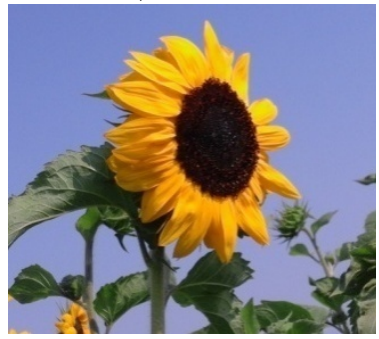

c) GZ21

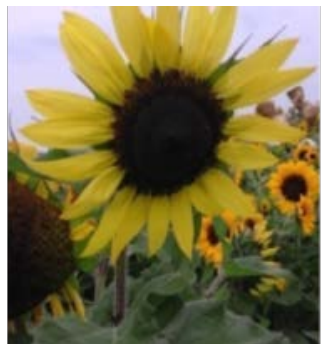

b) GZ16

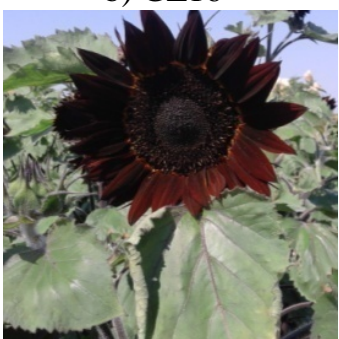

d) GZ37

Picture 1 a-d. Characteristic flowers of ornamental sunflower

\section{DISSCUSION}

Besides the quantitative, qualitative characteristics also showed great variability. The most prominent characteristics are in flower color. According to Cvejić et al. (2016) the color of the ray florets can vary from various shades of red to lemon-yellow. Genotype GZ13 has large flower heads with yellow-orange color and large number of ray florets. Color of disc florets was anthocian. Opposite to that, genotype GZ16 has small number of ray florets and they are lemon yellow. GZ21 is genotype with interesting yellow ray florets which are bent backwards. Genotype GZ37 is different from previous tree by the color of their florets. Ray florets of this genotype is anthocian and same color is present in disc florets. All tested genotypes are sterile, which is very important given the allergies that can cause pollen. This is consistent with the statement of Cvejić et al. (2010) that must be respected certain criteria in terms of flower appearance. In the case of the use of cut flowers for bouquets and flower arrangements this is of great significance.

To research the variability is an important starting point, which represents the basis for further breeding work. Knowing the morphological characteristics of the genotypes indicates the way of their use and their further exploitation. Thus the genotypes GZ13, GZ16, GZ21 and GZ37 may be used in garden landscaping but also as a cut flower. Due to a great height they are not suitable for pot, given that the lower genotypes $(40-60 \mathrm{~cm})$ are more favorable for this kind of use.

\section{CONCLUSION}

The development of horticulture and floriculture has led to the use of sunflower as an ornamental plant, in gardens, in pots or like cut flower. The results of four ornamental sunflower showed that the most variable morphological traits were number of days from germination till flowering of central head, number of days from germination till flowering of first lateral head, plant height and number of ray flowers in lateral heads. This indicates that the feature that carries a lot of decoration is very variable in these genotypes, and the combination can achieve unusual and harmonious landscape selection. Qualitative characteristics such as flower color, also showed great variability. Dominant color is yellow and combination of yellow-orange color. Genotyp GZ37 stands out with interesting anthocian ray florets. Base on the results all genotypes can be recommended as garden plants and cut flowers. 


\section{REFERENCES}

BOŠNJAK, D., RODIĆ, V., KARAPANDŽIN J.: Possibilities for the improvement of the soybean production in Serbia. Contemporary agriculture 62 (3-4), 266-275,2013.

CVEJIĆ, S., JOCIĆ, S.: Stvaranje hibrida dekorativnog suncokreta. Ratarstvo i povrtarstvo. Field and vegetable crops research. Institut za ratarstvo i povrtarstvo/Institute of Field and Vegetable Crops, Novi Sad. Field and Vegetable Crop Research, 47 (1), 147-152, 2010.

CVEJIĆ, S., JOCIĆ, S., MLADENOVIĆ, E.: Inheritance of floral colour and type in four new inbred lines of ornamental sunflower (Helianthus annus L.). The Journal of Horticultural Science and Biotechnology, 91:1, 30-35, 2016.

CVEJIĆ, S., JOCIĆ, S., PRODANOVIĆ, S., TERZIĆ, S., MILADINOVIĆ, D., BALALIĆ, I.: Creating new genetic variability in sunflower using induced mutations. Helia 34 (55): 47-54, 2011.

DRAGIČEVIĆ, V., PERIĆ, V., NIŠAVIĆ, A., SREBRIĆ M.: Antioxidants in soybean and sunflower grain. Contemporary agriculture 59 (3-4), 393-399, 2010.

KAYA, Y., JOCIĆ, S., MILADINOVIĆ, D.: Sunflower Technological Innovations in Major World Oil Crops Breeding (1st Edition, Vol. 1)., GUPTA, S.K. (Ed.), Springer, Dordrecht, Heidelberg, London, New York, p.85-129, 2012.

MIKLIČ, V. HLADNI, N. JOCIĆ, S. MARINKOVIĆ, R. ATLAGIĆ, J. SAFTIĆ-PANKOVIĆ, D. MILADINOVIĆ, D. DUŠANIĆ, N. GVOZDENOVIĆ, S.: Oplemenjivanje suncokreta u institutu za ratarstvo i povrtarstvo. Zbornik radova Institut za ratarstvo i povrtarstvo, Novi Sad/A periodical of scientific researsh on field and vegetable crops Institute of Field and Vegetable Crops Novi Sad, Serbia, 45 (1), 31-63, 2008.

Stat Soft Inc: Statistica (data analysis softwer system), version 13, http://www.statsoft.com, 2013.

ŠEĆEROV-FIŠER, V.: Nasleđivanje boje, forme cveta i granatosti kod dekorativnih sorti suncokreta. Magistarski rad, Poljoprivredni fakultet, Univerzitet u Novi Sad, 1985.

ŠEĆEROV-FIŠER, V. ATLAGIĆ, J. AND MARINKOVIĆ R.: Inheritance of the number of ray flowers in ornamental sunflower Review of research work at the faculty of agriculture Belgrade, Published by Faculty of Agriculture University of Belgrade FR Yugoslavia, 40 (1), 73-78, 1995.

\section{EVALUACIJA GENOTIPOVA SUNCOKRETA ZA UPOTREBU U HORTIKULTURI}

\section{Emina MLADENOVIĆ, Sandra CVEJIĆ, Jelena ČUKANOVIĆ, Gordana ŽERAVICA, Siniša JOCIĆ}

Izvod: Suncokret (Helianthus annuus L.) je vrsta sa intraspecijskom varijabilnošću, posebno u kvalitativnim karakteristikama. Sa aspekta hortikulture veoma je važan pravilan odabir genotipova naosnovu poznavanja njegovih osobina. Poznavanje osobina je važno kako bi se odabrali genotipovi koji se mogu gajiti u baštama i koji se mogu koristiti u proizvodnji rezanog cveta. Istraživanje je sprovedeno na Institutu za ratarstvo i povrtarstvo na Rimskim Šančevima, Novi Sad, Srbija. U eksperiment su uključena četiri genotipa ukrasnog suncokreta. Uočene su značajne varijabilnosti morfoloških osobina. Kvalitativne karakteristike kao što je boja cveta, takođe su pokazale veliku varijabilnost. Na osnovu rezultata istraživanja, ispitani genotipovi mogu se preporučiti za upotrebu u baštama i kao rezan cvet.

Ključne reči: ukrasni suncokret, varijabilnost, morfološke karakteristike, boja cveta

Received / Primljen: 09.06.2016.

Accepted / Prihvaćen: 04.07.2016. 